\title{
Rhetoric in Islamic Tradition: Paradigm and Its Development
}

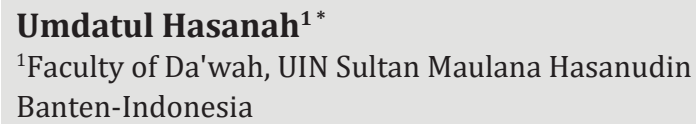

\begin{abstract}
Rhetoric has an essential role in developing Islamic civilization and da'wah. Rhetoric in the Islamic tradition has a dualistic paradigm that appears with two faces, specifically balaghah and khithobah. The character of balaghah is inherent in the rhetorical tradition, where the qualification of the message language is essential, including eloquence, meaning, and metaphor. In comparison, the khithobah character is attached to the quality aspects of the message content and the technique of delivering the message. This literature research found that the two faces of this rhetoric have further developments, one is progressive, and the other is still stagnant. The progress of balaghah is not only based on the role of Arabic as the Quran language but also the miracle of the Quran language itself. While khithobah is an essential part of delivering Islamic symbols, it is still considered a mere praxis and religious routine, and it has not developed as scientifically theoretic. Amid the limitations of the study of khitobah as part of Islamic rhetoric, this paper will elaborate on the dynamics and span developments periods.
\end{abstract}

Keywords: Rhetoric; Balaghah; Khithobah; Preaching of Islam

\section{Introduction}

Rhetoric meets different dynamics in every era and place (Rakhmat, 2011). The rhetoric that develops in the West is closely related to democratization and becomes a medium in expressing the freedom of opinion through public speeches (Rajiyem, 2005). The development of rhetoric relates to science and civilization (Clark, 2007). Similarly, there has been a development of rhetoric in the Islamic world time after time because rhetoric does not stand alone; it is always connected with other aspects. Rhetoric is part of the dynamics of religion and politics (Errihani, 2011). Rhetoric is also influenced by human social relations with their environment and culture (Safitri, 2017).

Many experts have carried out studies on Islamic rhetoric with various tendencies. There are at least three tendencies that the authors found. The first tendency is Islamic rhetoric as part of the da'wah method, as seen in the works of Al-Qardhawi, 2007 and Hasanah, 2020. The second tendency is to see Islamic rhetoric practically in da'wah activities (khutbah), as seen in Razi's writings,

\footnotetext{
*Author Correspondence: Umdatul Hasanah, Email : umdatul.hasanah@uinbanten.ac.id, Sultan Maulana Hasanudin State Islamic University, Jalan Jendral Sudirman No. 30 Panancangan Cipocok Jaya, Sumurpecung, Kec. Serang, Kota Serang, Banten 42118
}

Copyright (C) 2021 Umdatul Hasanah 
2013, and Samuri \& Hopkins, 2017. The third trend sees Islamic rhetoric historically as an essential part of the scientific arena and the development of Islamic civilization, as seen in the studies of Haque, 2010 and Høigilt, 2013. In the tendencies above, no one has mentioned the tradition and character of Islamic rhetoric and the position in the life and development of Islamic da'wah.

This paper tries to describe the development of Islamic rhetoric span developments periods. The progress of contemporary da'wah media, especially digital media, completes da'wah more lively in the public sphere and becomes a new challenge in the scientific development of Islamic rhetoric. Islamic rhetoric as part of the treasures of Islamic knowledge is essential to be repositioned in the scientific struggle. It is also practical to make Islamic rhetoric reach the fore and become a reference in conveying messages to the public, both in religious and other aspects. Al-Qardhawi's opinion that Islamic rhetoric is about spiritual issues and includes other aspects concerning various aspects of human life, both worldly and hereafter (Al-Qardhawi, 2007).

Islamic rhetoric has the peculiarity of combining the beauty of poetic and metaphysical language and combining language, politics, and religion (Hart \& Lind, 2011). Although the basic principles of religion have not changed, the way to spread religion will always change (Al-Qardhawi, 2007). Therefore, Islamic rhetoric will always modify according to the changing times themselves. The rhetorical tradition in Islam is practically closely related to people's lives because it is part of religious practice. However, theoretically, it is still rarely studied (Høigilt, 2013). Rhetoric, both scientifically and practically, has contributed to the development of civilization, including the development of Islamic civilization (Haque, 2010). The dynamics and development of rhetoric in the Islamic tradition are essential to examine because it is closely related to the progress of civilization and Islamic da'wah in building a harmonious life.

\section{Method}

The research method in this study uses the library method by taking from available literature sources related to the topic of study; related knowledge is then systematized into a discussion (Zed, 2014). The study was conducted using a historical, sociological approach. This study focuses on rhetoric in the Islamic tradition, which is sourced from books, scriptures, journals, and other scientific sources. The primary research sources are the rhetoric history and the rhetorical tradition in Islam and its evolution. Literature inquiries also strengthen data and arguments based on this discussion theme's initial assumptions.

\section{Result and Discussion \\ Islamic Rhetoric and Civilization}

Rhetoric as a science has been known since classical times and has become an essential part of the development of human civilization; through the development of the ability to speak in public, a popular term is a speech (Rakhmat, 2011). As a science of speaking, rhetoric has now developed more specific scholarship (Rakhmat, 2011). Rhetoric as part of philosophy has become the link between the two civilizations, the West and the East, with Muslim philosophers as the link between the two civilizations. Much 
of their thinking was influenced by Aristotle's thinking, evident in their works. One of them is Ibn Rushd, one of the Muslim scientists who was also influential in developing Aristotle's rhetoric in the Islamic world (Lea Clark, 2007). The development of Rhetoric at that time was closely related to philosophical thought, as seen from the use of dialectics, argumentation, and syllogism, which became an important part and influenced the Islamic discourse at that time. The link between rhetoric and philosophy is also seen in the debate of thought between Avverous (Ibn Rusyd) and Al-Ghazali thought, which impacted the development of Islamic thought (Haque, 2010).

The integration between Islam and science marked the triumph of Islamic civilization at that time. Islamic philosophers spread Islam through the development of science (Madjid, 1992). The source of Islamic teachings is used to produce knowledge. The development of Islamic civilization automatically becomes the development of Islam itself as a religion. The development of civilization is also very significant in Islamic Da'wah, which is developing in the East and the West and other parts of the continent. The spread of Islam is not only carried out with an an-sich religious, scientific approach through religious sermons but also scientific sermons and scientific dialogues. The scientific approach (science) integrates with religion, as conveyed in Islamic teachings, to encourage mastery of science (Nasr, 2005). The development of Islam is not only through the space of religion itself but also scientific forums, which become a space for the interaction of civilizations that influence the development of Islam. The development of Islamic science and civilization is getting broader in line with the opening of speech freedom to convey arguments, ideas, and thoughts.

The development of rhetoric in the socio-religious domain also emerges in Islamic society. Rhetoric became one of the means of developing Islamic civilization and da'wah, which subsequently developed widely in philosophy, politics, law, social, and even religion (Rakhmat, 2011). Rhetoric in the past developed as a public dialogue, both in religious sermons, social and political discourses between ethnic groups, and camps/groups (National, 2003). In addition, scientific discourses between sects have also developed, including among Mutakallimin (Høigilt, 2013). Islamic rhetoric has developed in oral and written rhetoric carried out by previous Muslim scholars to spread their ideas, thoughts, and fatwas. The rhetoric comprises many scholars or intellectuals to counter other ideas and thoughts.

The rhetoric tradition, both in oral or written discourses, has practically existed in the Islamic society traditions, even long before the Islamic era, for example, discourses to raise the spirit of the struggle between tribes and expressing feelings through poetry. After the Islamic era, efforts to convince Islam's truth and spread it was carried out with various approaches, such as logic through hujjah, dialectics, and even language style, which later gave birth to preachers or oratories in Islamic circles. The preachers are the bestchosen people selected by the community and the state, as occurred during the Islamic caliphate and in the current government of Islamic countries. The preachers should have mastery of Islamic material and transmit with beautiful and high-quality language. In some countries, preachers are part of the state's 
duty to influence the broader public through sermon messages that have been designated both in content and narrative and diction by the state, one of which is Malaysia (Samuri \& Hopkins, 2017).

In the Indonesian context, the involvement of the state in da'wah matters or what is termed as structural da'wah is not only control over the implementation of da'wah in the society but also as a state responsibility to ensure the passage of religious life as mandated in the constitution (Zain \& Maturidi, 2021). The da'i or preachers are an essential component of inviting and spreading goodness as a role model for the community. The preachers must have good religious knowledge and transmit messages in excellent and exciting language. The aspect of language has been an essential concern for preachers since ancient times.

During the Umayyad dynasty, famous figures such as Yazid bin Abihi and Hajjaj bin Yusuf as-Saqafi were two preachers who relied on language aesthetics to attract their listeners (Nasional, 2003). In addition to using logic and evidence, the preacher's speeches also elaborated on the attractiveness of language in public discourses. Expressions of the standout of language appear in poems and public speeches. These two specializations have become essential traditions in Islamic society and have even been well-known to Arab society before Islam. The rhetorical ability at that period put the owner or expert in a high social class in society (National, 2003; Rakhmat, 2011). Since ancient times, Khatib or orator has become an essential status.

The khitobah tradition in socio-political and religious life has been known since preIslamic times and has grown. At that period, the preacher/orator used language style (uslub) either in prose, rhyme, or heroic words delivered during a speech. This language style is used to attract attention and encourage the community, both in social and religious messages, and to foster a fighting spirit in inter-tribal warfare. The speech style also often uses wisdom or evidence in arguing or inviting people to leave the practice of worshiping idols. For example, as did Qus bin Sa'idah, one of the popular preIslamic preachers who were monotheistic and believed in the resurrection, he delivered sermons that invited the truth of monotheism.

Poetry and prose after the presence of Islam developed in the science of balaghah. Meanwhile, the tradition of speech (khithobah) is also an essential part of the Islamic religious tradition, even in a series of worship. The Prophet and his companions constructed many types of speeches (khithobah), both khithobah in prayer, teaching, and others. One of the sermons that received significant attention was the Wada sermon performed by the Prophet Muhammad during the Wada pilgrimage. This last sermon of the Muhammad Prophet hypnotized the people in an atmosphere of compassion and became a milestone in developing the social life of the larger community (Khatibah et al., 2018). Similarly, sermons during the companions' time, one of which was recorded in a monumental work, in this case, is "Nahjul Balaghah," a collection of speeches by Syaidina Ali, the fourth Caliph of the Khulafaurrasyidin (Radhi, 2006).

Historical sources of rhetoric in the Islamic tradition, both in practice and thought, continue to develop in two paradigms, specifically balaghah and khithobah. Balaghah is multiplying as linguistics in the Islamic tradition, while khithobah is considered a 
practical aspect. Khitobah is considered the art of conveying messages in public, and it is often narrowed down to merely a religious activity. According to Al-Bitar, although khithobah is well known in the historic Islamic world, academically as a theory, it has not been widely explored (Albitar, 2009). Currently, the khitobah study is included in a narrow-angle as one of the methodology elements of da'wah science. This narrow view of the study of khitobah causes the limited theoretical development of Islamic rhetoric, especially in the perspective of khithobah.

In line with Al-Bitar's opinion above, Jan Scholz also stated that the rhetoric developed in the Arab-Islamic world focused more on language aesthetics and ethics through developing fluency or balaghah abilities. These ethics and aesthetics also affect the technical rhetoric used by Islamic preachers (Scholz, 2018). Although still pays little awareness to the entimem and dialectic of rhetoric and the use of syllogisms. However, rhetoric in the Islamic tradition gives little space to the importance of style and performative as in Western rhetoric (Scholz, 2019). The style or performance in Islamic rhetoric is more attached to the method, which is one of the elements in studying da'wah science.

As a result of technological developments, digitalizing da'wah has become a new trend that directly or indirectly impacts changes in da'wah rhetoric (Trilaksono et al., 2021). The delivery of Islamic da'wah through public media or social media platforms, such as YouTube, Instada'wah, Tweeter, Line, and Tik Tok, has changed the format, content, method, and even rhetorical style in general. Excellent and attractive language, diction, and narration in delivering religious and other messages are essential concerns in Islam.
Islamic rhetoric, which is humanistic and full of messages of unity and compassion, has been misunderstood by certain circles through confrontational diction (Hart \& Lind, 2011). Through an open space that targets a broader circle of people without boundaries, Da'wah, if carried out with frivolous narrative, diction, and style, will damage the image of Islamic rhetoric itself and on relations and social life in general.

\section{Rhetoric Language and Islamic Da'wah}

Rhetoric developed in the Islamic tradition has two scientific sides: ilm' alBalaghah and al-Khithabah. Both are now expanding with their characteristics and specifications. Balaghah science is closely related to linguistics and literature, which historically have genealogy with the traditions of Arab society even long before the growth of Islam. In comparison, khithobah is a process of Islamic symbols in messages, advice, invitations in religious matters to increase devotion to Allah SWT.

Scientifically, balaghah was born, developed, and established after Islam arrived. Theoretically, balaghah has developed rapidly, much in demand and studied by producing creations that complete balaghah science expands. The emergence of balaghah science is often associated with three things that contribute significantly to the development of balaghah science, specifically: the science of the Qur'an, linguistics / alulum al-lughawiyyah, and literary science / al-ulum al-adabiyah (Zaid, 2006). As part of linguistics, balaghah has three primary studies, specifically ma'ani, bayan, and badi' (Al-Hasyimi, 1999). Apart from being a science, balaghah has also developed as a tradition in Arab society in poems and poetry. 
In the Islamic period, balaghah grew and became an independent scientific discipline. The development of balaghah scholarship is closely related to Arabic as the Qur'an language. The presence of the Qur'an with a gorgeous language structure becomes an essential part of the development of balaghah science. The attractiveness of the Qur'an language as a miracle amazed literary experts who conquered the arrogance of the polytheists and transformed them into monotheism believers. Many of the polytheists turned to faith and became defenders of the Qur'an after hearing the readings and contents of the Qur'an, one of which was Umar Ibn al-Khattab, who converted to Islam religion after hearing the reading of the Qur'an. The majesty of the Qur'an, which became a miracle influenced by the content and language aspects, has produced new sciences to understand the miracles of its language, namely al-I'jaz wa ithnab (Al-Hasyimi, 1999).

The development of the balaghah science is related to Islamic da'wah's journey from the beginning to the present. Through the science of balaghah, the Qur'an miracles are increasingly understood, giving rise to higher admiration and belief in the Qur'an and in the One who sent down the Qur'an to the earth, Allah SWT. The attractiveness of the Qur'an language is the media for da'wah that brings to an awareness of acceptance of Islamic thought. The Qur'an has excellent language structure, and also its commands are easy to understand by humans with various levels of thought. The message that Allah conveyed to humankind in the Qur'an is easy to understand, although there are various ways of understanding it. Some interpret the Qur'an language word-for-word, some interpret it symbolically, and some even interpret it in essence. The quality language, the beauty of the structure, the aesthetics, and the ethics of the Qur'anic sentences can be felt in general from various levels.

In the pre-Islamic and Islamic periods, the preachers mastered the balaghah used in their sermons, both in reciting speeches and celebrations, including religious celebrations. Excellent and attractive speaking skills show their personal and leadership qualities. One of the abilities of the preacher is the use of narration with beautiful language and accurate intonation. They are generally proficient in language style in every moment of their speech. The preachers in the past were also known as people who spoke loudly used to make speeches on mounds of earth and their vehicles (camels) so that their audiences could hear them (Nasional, 2003). In general, the rhetorical style of the preacher in Islam uses the rhetorical style of the Qur'an. The beauty of the Qur'an language and a rationallogical rhetorical approach with arguments and wisdom to stick in the hearts of audiences (Rakhmat, 2011).

\section{Rhetoric and Performance in Sermons}

Khutbah is religious rhetoric that exists in Islam. Rhetoric and performance in delivering religious and non-religious messages are essential topics. There are at least three significant genres of rhetoric, specifically; the epistemological genre, which was developed in the philosophical and psychological traditions, and the belles lettres genre, which developed in the language literature tradition, and the elucasionist genre (style), which developed in the acting tradition of theatrical style. In reality, the three essential components of rhetoric cannot be separated 
and are often carried out simultaneously. Mastery over combining these three aspects is the ideal of performance in rhetoric in general and in religious rhetoric as in sermons. The performance and style of the preachers in delivering religious sermons is an attraction for the congregation (Scholz, 2018).

Khutbah is an essential element as part of Islamic religious practice. In terms, sermons are speeches or lectures in delivering messages or advice related to religion (National, 2003). The person who delivers the sermon is called a preacher. The word khotib (خطيب) is derived from the word (خطب khotoba) then refers to several words, including khotbun (خَطْبُ),

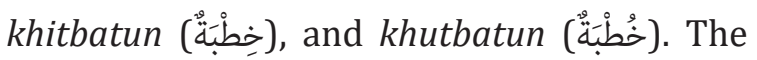
three meanings respectively mean "case/ affair," "application," and "talk of a preacher." According to Abu Ishaq, khutbah means: implies speech in the form of rhythmic prose." As for the Tahdzib AlLughoh dictionary, "Khutbah" is equated with "Minutes/letters" where both have a beginning and an end in their composition (Mandzur, 2013).

Based on the above definition, a sermon delivers a message specifically only related to religious content and context, distinct from an ordinary speech in general related to the delivery of messages about many things. There are various types of sermons in the Islamic tradition, both in a series of prayers and outside prayers. There are Friday worship sermons in the series of prayers, Eid al-Fitr sermons, Eid al-Adha sermons, and prayer sermons for rain / istisqa. The solar eclipse prayer sermon / kusuf, the lunar eclipse prayer sermon / khusuf, and the Arafah sermon are performed during the pilgrimage in the Arafah field. While the sermon outside the prayer of which is the marriage sermon.
The preacher or khatib has a vital position in Islamic society and is included in specific social structures in the religious domain after the mufti, Qadhi, and ustadz (teachers). The preacher's position is fundamental because his duties are dignified and crucial in Islamic symbols. Therefore, the preacher in Islam is more expansive than their influential position in implementing worship (National, 2003). The preacher has a vital position socially and as a determinant of worship because the sermon is an essential part of Friday prayers and Eid prayers. In its implementation, the sermon must be based on religious rules, both in the delivery technique, the media used, the content of the message, the time and place, and the procedures regulated by religious law. Sermons in this category are syar'iyyah sermons. Although the scholars differ on the pillars of the sermon, all agree that the sermon (Friday worship) is obligatory based on the word of God (Q.S. Al-Jumu'ah verse: 11).

In practice, the sermon has two categories; the first category is the sermon which is a series in the implementation of prayer. Some of the prayers include the implementation of the sermon, including Friday worship, Eid al-Fitr, Eid al-Adha, eclipse prayers (Kusuf \& Khusuf), praying for rain (istisqa), and sermons during the pilgrimage (khutbah Arafah). The type of Khutbah above has been strictly regulated in the Shari'ah with straightforward guidance. This type of sermon is called a syar'iyyah sermon. In comparison, the second category is sermons that are not strictly regulated in the Shari'ah but become a daily practice in the religious life of Muslims, especially in Indonesia. This second type of sermon is called a sermon ghair syar'iyyah. These two types of sermons have different characters and guidance. 
Syari'iyyah sermons are sermons whose procedures have been strictly regulated by Shari'a, both the terms of the preacher, content, time, and other aspects as part of the prayer worship, such as the implementation of the Friday worship sermon, which is carried out before the implementation of the prayer, has become a shari'a provision. Likewise, the implementation of Eid al-Fitr and Eid al-Adha sermons, Kusuf prayer sermons, Khusuf prayer sermons are carried out after the prayer. The sermon in prayer is also bound by the Shari'ah rules, not only for the preacher himself but also for the congregation (Hasanah, 2020b).

Sermons are included in syar'iyyah because they are carried out simultaneously, with the implementation of prayer being internal, specifically among Muslims. Sermons generally aim to remind and increase piety to Allah SWT. The preacher in the syar'iyyah sermon is also unique and limited in terms of gender, and only men are allowed to become preachers. Women are not allowed to become preachers among men, just as they cannot become religious leaders (imam) of praying in front of a male congregation. Meanwhile, women can become preachers if the congregation is only women. Including the marriage sermon, although it is not part of the prayer worship, the preacher at this sermon is generally done by men, such as guardian judges or guardians of marriage.

In general, the genre of fiqh agrees not to allow women to become priests for men. However, a story tells the female preacher's appearance among the sahabiyah, Umm Waraqah as an old male congregation's worship leader (imam). This hadith is often the basis for arguments from feminist circles (Suryadilaga, 2011). In general, fiqh scholars reject the appearance of female priests and preachers in front of male congregations in implementing sermons that are included in the series of prayers. Meanwhile, if the sermon is not part of a single series of prayers, such as in the form of a short religious course (seven-minute lecture), then it is permissible for women to do it. Short religious lectures are usually carried out before or after prayers, both in fardlu prayers and sunnah prayers. Female da'i often conduct short religious lectures, even though there are male congregations in them, as is generally done in short religious lectures after the early morning prayer, midday prayer, and before tarawih (Hasanah, 2020b).

The Islamic world once criticized the actions of Amina Wadud, a Muslim feminist, when she appeared as a preacher and imam for Friday worship prayers in front of male congregations in 2005 in America. Damanhuri wrote about this controversy in Khazanah Republika, "recalling the controversy over female priests" (Republica, 11 June 2010). Not only priests who are strictly regulated in khithobah syar'iyyah, but ma'mum (follower of prayer) is also regulated in such a way according to shari'ah provisions.

The distinction between the sermon in the series of prayers and the sermon outside the series of prayers is that prayer is a oneway monologue without feedback and is not interactive. When the preacher delivers his sermon, the congregation is obliged to listen because listening to the sermon is part of a series of worship, especially on Friday worship sermons. The congregation is also passive. In this case, there is no dialogue or interruption. There should be no movement, speech, or action during the sermon because it can invalidate the prayer. As stated in verse, 
"And when the Qur'an is read (Khutbah) then listen carefully and pay attention so that you get mercy" (Q.S. Al-A'raf; 204). Intellectuals agree that this verse is closely related to the sermon (Shihab, 2011). In this case, the congregation becomes a communicant who is passive and must obey and respect what is conveyed by the preacher.

The second type of sermon is the ghair syar'iyyah sermon. This type of sermon is a religious sermon, but it is not carried out in a series of prayer worship stipulated in the Shari'a. This type of sermon is open in scope, whether carried out within the Islamic community or the community in general. Muslims make sermons in religious lectures an essential part of various moments of life. Religious sermons in recitations are carried out at every momentum, both in religious, social and even celebrations and commemorations of Islamic holidays (Millie, 2013).

The types of sermons in the ghair syar'iyyah category are lectures, speeches or tausiyah, mauidhah hasanah, which are carried out anytime and anywhere in various activities. Ghair syar'iyyah is also regulated in Islamic ethics in general and social ethics. However, the general ethics of its implementation still refers to the ethics outlined in the normative sources of Islam, specifically the Qur'an and Sunnah. According to Buya Hamka, understanding religious ethics and wisdom or ethics that are generally understood and accepted in society must be well understood by the preacher (Hamka, 2018). A similar opinion was also expressed by M. Natsir, that tradition and local wisdom are one aspect that must also acquire the attention of preachers (Natsir, 1996).
Besides having different characteristics of implementation and prerequisites, the two types of sermons above also differ in the delivery system. The systematic delivery of sermons is generally carried out in a series of prayers, and outside prayers have differences. For example, the execution of the prayer sermon usually begins with reading basmalah, tahmid, praise to Allah, sholawat, creed, and calls to obey Allah, advice/messages, prayers, and closing. Meanwhile, sermons outside of prayers such as lectures and tausiyah are generally open with greetings, opening/ preambule, introductions, descriptions interspersed with interactions, and others such as humor, followed by conclusions and closings, and prayers.

Public response is an essential concern in the study of rhetoric which is usually applied in the type of sermon ghair syar'iyyah. In this second type of sermon, the systematic delivery of the sermon is varied and more flexible depending on the style of the preacher himself. Some preachers open it by greeting first, sometimes by reading sholawat together with the congregation, or starting by telling stories or singing, rhymes, or anything that is entertaining or arouses the enthusiasm and attention of the audience. Even the audience's response both during the sermon and after it became the indicators that showed the speaker's success in influencing the audience (Rakhmat, 2011).

Preachers, both on religious and other occasions, make various efforts so that their messages arrive, are accepted, and attract attention and influence the audience. Delivering messages interactively and excitingly in front of the congregation is essential for the ghair syar'iyyah sermon. An essential prerequisite is the ethos component 
for good preachers, especially in ghair syar'iyyah sermons. Besides, the preacher must have an ethos component in the form of credibility, qualifications, and competence, and he must also be able to manage and convey messages with a touch of logic and emotion that also affects the power of reasoning and enters the feelings of the audience. Logos and pathos (in Aristotle's terms) are prerequisites for preachers as orators (Hasanah, 2020a).

The delivery of ghair syar'iyyah sermons is flexible and unrestricted. Flexibility is noticed in the preacher's place, time, material, and gender aspects, either male or female. From the aspect of time and momentum, in the context of Indonesian society, all events of human life, both personal and social, become an essential momentum that can involve religious discourse. Especially on religious events or Islamic holidays, lectures or sermons on ghair syar'iyyah become a mandatory agenda (Millie, 2013). Furthermore, ghair syari'iyyah sermon activities are found in recitation activities regular taklim assemblies that cannot be separated from religious thought with various formats (Hasanah, 2020 a).

The openness of the ghair syari'iyyah sermon is also gender-responsive, not restricted to a specific gender. Women have become the dominant group in public religious life through taklim groups, both as congregations and ustadzah (teacher) or muballighah (Hasanah, 2017). Ghair syar'iyyah's sermon provides an excellent opportunity for women to be actively involved in it, although in the presence of men, there is no prohibition for women to be a ghair shari'iyyah preacher. Ustadzah or muballighah are used to giving tausiyah, lectures, studies, recitations, or mauidhah hasanah in front of male congregations. A common sight found in various scientific assemblies, taklim assemblies, tabligh akbar, and other religious and social commemorations. The openness and flexibility in this type of sermon are also noticed from the aspect of the place. Sermons are carried out in assemblies and places of worship such as mosques and prayer rooms. In addition, the sermon can also be carried out in other public places such as; halls, stadiums, fields, residents' houses and even hotels, and cafes and hangouts for millennial urbanites. The openness of this sermon model makes the ghair syari'iyyah sermon so familiar to the Indonesian people (Millie, 2013)

\section{Conclusion}

The Islamic rhetoric tradition that developed in the past was wider than speeches and delivered public messages and opinions. The dialectical tradition, argumentation in conveying messages in public, is also used to disseminate Islam. Rhetoric that develops in the Islamic tradition is mastery of oral rhetoric, through speeches and scientific dialogue, as is done by mutakallimin, and through writing. Another aspect that accompanies the rhetorical process is the performance and charisma of the preacher, who can influence and move the audience.

Rhetoric in the Islamic tradition recognizes two crucial aspects: the language factor and the message delivery process factor. First is the attractive, fluent, and exciting language aspects of the message. The use of language that follows the context and necessities as well as the intended target is carried out through the balaghah approach, which has three essential parts including; 1) ma'ani, the science of ma'na, 
specifically seeking conformity of meaning to the circumstances and conditions in which the language is spoken. 2) al-Bayan, the importance of metaphors, and 3) badi', precisely fluency in adorning language. Second, the delivering sound, engaging, communicative, persuasive, and ethical message transmission in influencing the audience. The process is carried out through messages that touch emotions, thoughts, actions, performances, and charisma that arouse the audience's attraction. These aspects are studied in the science of al-fann al-khithobah or the art of delivering speeches.

The role of rhetoric is essential in Islam development, not only as a base practice in the life of Muslims but also as a part of the development of civilization and Islamic symbols. Struggles to revive and redevelop Islamicrhetoricin thegrand tradition of science are urgently carried out during digital media development. This paper has many limits, only presenting an overview of the Islamic rhetorical tradition and its development historically and sociologically, especially regarding the development of Islamic rhetoric in the character of khithobah/sermons and their implementation. With the limitations of this paper, it is hoped that the following research will be more comprehensive. This research is expected to make a scientific contribution to the scientific development of Islamic rhetoric and revive Islamic rhetoric both in academic discussions and in practice for the life of da'wah throughout the ages.

\section{Bibliography}

Al-Hasyimi, A. (1999). Jawahir al Balaghah (Cet ke 1). Maktabah al Ashriyah.

Al-Qardhawi, D. Y. (2007). Retorika Islam:
Bagaimana seharusnya menampilkan wajah Islam (edisi Indonesia) (kedua). Pustaka Al-Kautsar.

Albitar, M. (2009). The Jewels of Rhetoric Jawahir Al-Balaghah Arabic Rhetoric Thesis Translation Project Case Study. Hawaii Pacific University.

Ali Asyri Zaid. (2006). Al-Balaghah Al"Arabiyah: Tarikhuha Masadiruha Manahijuha. Maktabah al Adab.

Errihani, M. (2011). Managing religious discourse in the mosque: The end of extremist rhetoric during the Friday sermon. Journal of North African Studies, 16(3). https://doi.org/10.1080/136293 87.2010.515411

Hamka. (2018). Prinsip dan Kebijaksanaan Dakwah. Gema Insani Press.

Haque, M. (2010). Impact of the Controversy between al-Ghazali and Ibn Rushd on the Development of Islamic Thought. Transcendent Philosophy Journal, 11.

Hart, R. P., \& Lind, C. J. (2011). The rhetoric of Islamic activism: A DICTION study. Dynamics of Asymmetric Conflict, 4(2), 113-125.

Hasanah, U. (2017). Majelis taklim perempuan dan perubahan sosial pada masyarakat perkotaan. PKBM "Ngudi Ilmu".

Hasanah, U. (2020a). Kualifikasi Da'i: Komparasi Konseptual Retorika Dakwah dan Retorika Aristoteles. Jurnal Komunikasi Islam, 10(2), 256-275.

Hasanah, U. (2020b). Retorika Dakwah Kontemporer. Media Madani.

Høigilt, J. (2013). Islamist rhetoric: Language and culture in contemporary Egypt. In Islamist Rhetoric: Language and Culture in Contemporary Egypt. 
Taylor and Francis. https://doi. org/10.4324/9780203841778

Khatibah, K. K., Yuslem, N., \& Abdullah, A. (2018). PROPHET MUHAMMAD'S RHETORIC; An Analysis of Prophet Muhammad Speech on Wada'Pilgrim in Sahih al-Bukharī. INTERNATIONAL JOURNAL ON LANGUAGE, RESEARCH AND EDUCATION STUDIES, 2(2), 281293.

Lea Clark, C. (2007). Aristotle and Averroes: The Influences of Aristotle's Arabic Commentator upon Western European and Arabic Rhetoric. Review of Communication, 7(4). https://doi. org/10.1080/15358590701596955

Madjid, N. (1992). Islam Doktrin dan Peradaban. Paramadina.

Mandzur ibnu. (2013). Lisan al-Arab (ke-3). Dar al-Hadits.

Millie, J. (2013). The situated listener as problem: 'Modern' and 'traditional' subjects in Muslim Indonesia. International Journal of Cultural Studies, 16(3), 271-288.

Nasional, D. P. (2003). Ensiklopedi Islam. PT Ichtiar Baru Van Houve.

Nasr, S. H. (2005). The need for a sacred science. Routledge.

Natsir, M. (1996). Fiqhud Da'wah (ke-10). Capita Selecta.

Rajiyem. (2005). Sejarah Dan Perkembangan Retorika. Humaniora, 17(2), 142-153.

Rakhmat, J. (2011). Retorika Moderen Pendekatan Praktis. Rosda Karya.

Safitri, D. (2017). Kontestasi Retorika Islam Nusantara. Ilmu Dakwah: Academic Journal for Homiletic Studies, 11(2), 235256.
Samuri, M. A. A., \& Hopkins, P. (2017). Voices of Islamic Authorities: Friday Khutba in Malaysian Mosques. Islam and ChristianMuslim Relations, 28(1), 47-67. https:// doi.org/10.1080/09596410.2017.1280 916

Sayid Syarif Radhi. (2006). Nahjul Balaghah, edisi Indonesia. Lentera.

Scholz, J. (2018). Dramatic Islamic Preaching: A Close Reading of 'Amr Khālid. Religion and Aesthetic Experience, 149.

Scholz, J. (2019). Modern Arabic rhetorical manuals: A transcultural phenomenon. In Engaging Transculturality (pp. 170184). Routledge.

Shihab Quraish. (2011). Kemukjizatan AlQur'an: Ditinjau dari aspek kebahasaan , isyarat ilmiah dan pemberitaan ghaib. Mizan.

Suryadilaga, M. A. (2011). Hadis-Hadis tentang Perempuan sebagai Imam Shalat. Musãwa Jurnal Studi Gender Dan Islam, 10(1), 1-32.

Trilaksono, B. H., Prasetyawan, W., Amirudin, A., \& Rizky, K. (2021). MEDIA RETORIKA DAKWAH PADA ERA MILENIAL. Q1 Jurnal Komunikasi Dan Penyiaran Islam, $1(1)$.

Zain, A., \& Maturidi, M. (2021). Interreligious Relations in the Structural Da'wah Framework. KOMUNIKA: Jurnal Dakwah Dan Komunikasi, 15(1), 97-109.

Zed, M. (2017). Metode Penelitian Kepustakaan (cet ke-4). Yayasan Pustaka Obor Indonesia. 